\title{
ON THE HEPATIC FLORA OF SAYAN MOUNTAINS (SOUTH SIBERIA)
}

\section{К ФЛОРЕ ПЕЧЕНОЧНИКОВ САЯН (ЮЖНАЯ СИБИРЬ)}

\author{
NADEZHDA A. KONSTANTINOVA \& ARKADIJ N. VASILJEV ${ }^{2}$ \\ Н. А. КОНСТАНТИНОВА' и А. Н. ВАСИЛЬЕВ 2
}

Abstract

An annotated list of new or interesting species of hepatics of the Sayan Mountains is presented. It includes 43 taxa new for Sayan, 25 of which are new for South Siberia, and Diplophyllum abtusatum is new for Eurasia. A number of species are reported as much more common in Sayan than it was known previously. The peculiarities of distribution of phytogeographically interesting species are discussed. The new combinations are suggested for ten species of the genus Schistochilopsis (Kitag.) Konst., comb. nov. (= Lophozia subgen. Schistochilopsis Kitag., Massularia Schljak., nom. illeg.) and for Cephaloziella arctogena (Schust.) Konst., comb. nov. (Cephaloziella rubella subsp. arctogena (Schust.) Schust. \& Damsh.).

Резюме

Приводится аннотированный список новых для Саян, а также редких видов печеночников. 43 вида - новые для Саян, из них 25 впервые отмечены дия Южной Сибири, a Diplophylhum obtusatum Schust.- впервые для Евразии. Многие виды, ранее считавшиеся редкими, оказались широко распространенными в Саянах. Обсуждается также распространение ряда видов, интересных в фитогеографическом отношении. Предложены новые комбинации для 10 видов Schistochilopsis (Kitag.) Konst., comb. nov. (= Lophozia subgen. Schistachilopsis Kitag., Massularia Schljak., nom. illeg.) и для Cephaloziella arctogena (Schust.) Konst. comb. nov. (Cephaloziella rubella subsp. arctogena (Schust.) Schust. \& Damsh).

\section{PHYSIOGRAPHY}

Eastern and Western Sayan Mountains are situated in the central part in South Siberia. Eastern Sayan (ES) is a mountain range of about $1000 \mathrm{~km}$ long stretching from NW to SE. The relief of its NW part is of medium elevation, and the mountains have flat tops, while southeast part has an alpine topography. Here the steep slopes are cut with hollows and valleys, the mountain tops are often sharp and the crests are jagged. The Manku-Sardykh Peak (alt. 3491 $\mathrm{m}$ ) of Eastern Sayan is the highest point of Sayan. Western Sayan (WS) extends from south-west to north-east and is also about 1000 $\mathrm{km}$ long. Alpine relief forms are predominating. The elevations reach $1400-3000 \mathrm{~m}$.

The climate of the Sayan is determined by its central position on Eurasiatic continent as well as by local conditions created by the moun- tains with opened out slopes or deep gorges. The mean annual temperature in the area is below zero, the mean temperature of January at the $900-1400 \mathrm{~m}$ elevation is from -17 to $-26^{\circ} \mathrm{C}$, and that of July is $+12^{\circ}-+18^{\circ} \mathrm{C}$. Precipitations are extremely uneven. Humid air masses come from the west or northwest causing annual precipitation of $1200 \mathrm{~mm}$ on the northern and western slopes of ES. On the other hand, southern and eastern slopes, hollows and valleys are in rain-shade receiving only 200 to $800 \mathrm{~mm}$ annually. The essential amount of annual precipitation falls in summer. The duration of snow cover varies from 200 to 240 days, sometimes 300 days.

\section{Historical Background, Materials \& METHODS}

Until last decade only few papers including data on several common hepatics were published (Martyanov, 1882; Arnell, 1898; Elenkin, 1902;

1. Polar-Alpine Botanical Garden, Kirovsk-6, Murmansk Prov 184230 Russia. - Россия 184230 Мурманская обл., Кировск-6, Полярно-Альпийский ботанический сад.

2 - Biological Faculty of Krasnoyarsk Pedagogical Institute, A. Lebedeva str., 89, Krasnoyarsk 660049 Russia - Poccuя 660049 Красноярск, А. Лебедева, 89, Красноярский педагогический институт, Биологический факультет 


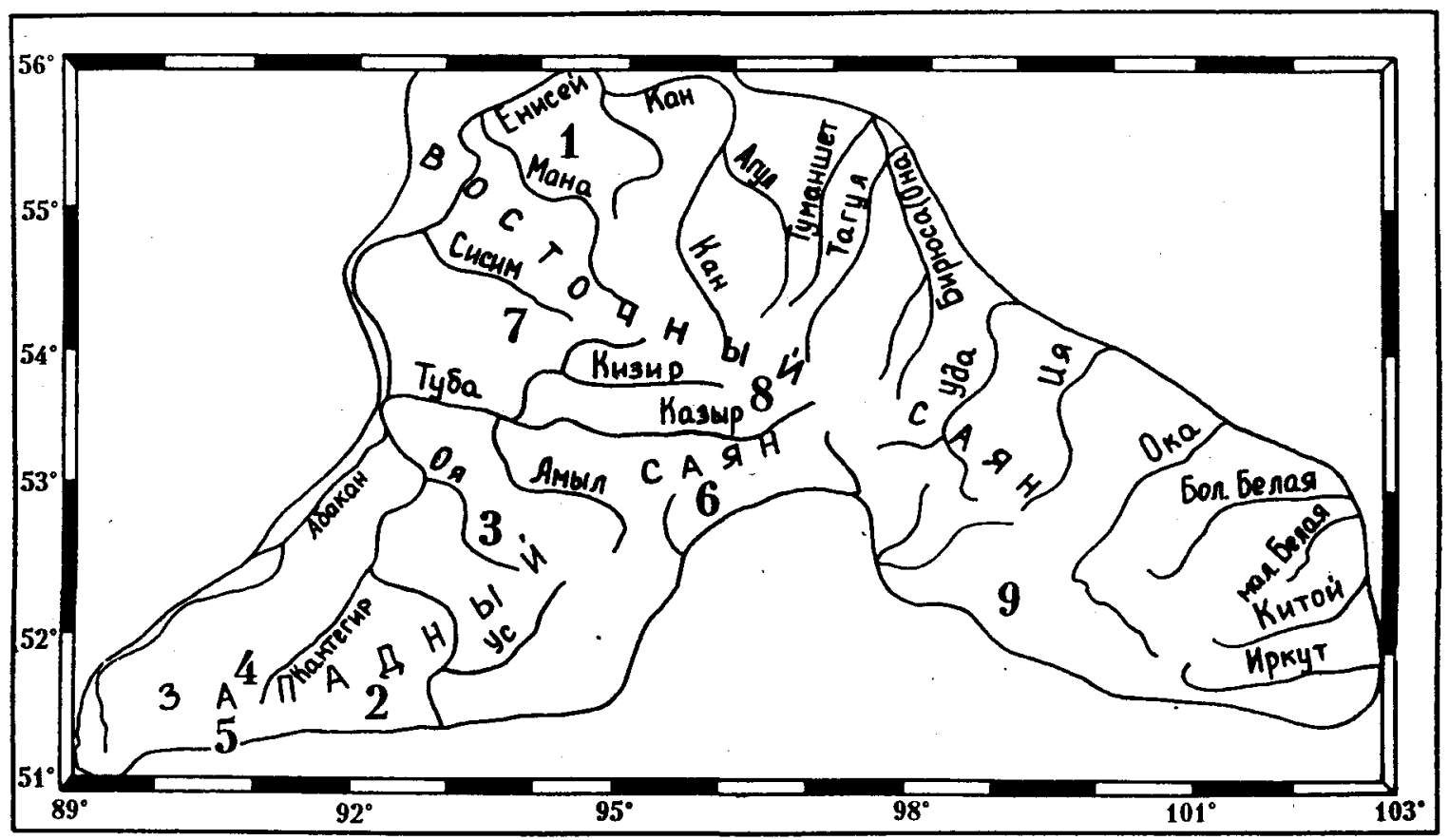

Fig. 1. Map of Western Sayan (Западный Саян) and Eastern Sayan (Восточный Саян) with the collecting localities: 1 - Nature Reserve State "Stolby"

2 - Sayano-Shushenskiy Nature Reserve, Range Khemchikskij - Саяно-Шушенский заповедник, хр. Хемчикский.

3 - Range Kulumys, Range Oiskij,

Malyi Kebezh River, Medvezh'ya and Olenya Rechka

4 - Karasibo (Kharasip) River and Karasu River

5 - Ona River, Malyi On River and Bolshoi On River

6 - Range Ergak-Torgak-Taiga

хр. Кулумыс, хр. Ойский, р. Малый Кебеж, Медвежья и Оленья Речка

7 - Sisim River near railway stations Shchetinkino and Kazyr -

8 - Vala Range, Kryzhina Range, Grandioznyi Peak,

Mezhdurechnoe Lake, Prochodnaya River

9 Topografov Peak, Upper Tissa River

pp. Карасибо (Харасип) и Карасу

pp. Она, Малый Он, Большой Он

хр. Ергак-Торгак-Тайга

р. Сисим близ ж. д. ст. Шетинкино и Казыр

хр. Вала, хр. Крыжина, пик Грандиозный,

оз. Междуреченское, р. Проходная.

пик Топографов, верховья р. Тисса

Brotherus \& Savicz, 1932; Kaalas, 1918; SaviczLjubitskaya, 1961). Later the knowledge of the hepatics from South Siberia and Sayan particularly was greatly contributed and summarized by Vana (1988). Recently Vasiljev (1992) published the moss and hepatic flora of Nature Reserves "Stolby" and "Sayano-Shushenskij" which are situated in Eastern and Western Sayan respectively.

The present paper is based on the determinations of the specimens collected mainly by A.N. Vasiljev in the course of his extensive field research in Sayan (Fig. 1). Some specimens collected by L. V. Bardunov together with Vasiljev as well as A. E. Sonnicova (indicated in the list of species as L. B. and A. S. respectively) were also studied. Determinations of Vasiljev were revised by the senior author and some taxa published by Vasiljev (1992) were excluded. About 700 herbarium specimens have been de- termined, and many interesting species were found. In the following list the new taxa for South Siberia and Sayan are presented, as well as some rare species or species previously considered as rare. The species in the list are arranged according Schljakov (1976, 1979-1982), the nomenclature is based on that in Konstantinova \& al., (1992), with exception of some changes mentioned below.

As it was found by R. Grolle (pers. corresp.), the name Massularia was validated for a genus of vascular plants (Rubiaceae) earlier, than for the genus of hepatics, and therefore is inapplicable to the latter. In some modern studies this genus is regarded as subgenus Schistochilopsis Kitag. of the genus Lophozia (cf. Schuster, 1988; Bisang, 1991). However, we believe that it is more convenient to work with small genera and follow Schljakov $(1972,1985)$ that this subgenus to be treated as separate genus. 
Schistochilopsis (Kitag.) Konst., comb. nov. - Lophozia subg. Schistochilopsis Kitag. J. Hattori Bot. Lab. 28: 289. 1965; Lophozia subgen. Massula K. Muell., Ber. Deutsche Bot. Ges., 57: 341. 1939, nom. nud.; Massula (K. Muell.) Schljak. - Nov. Syst. Plant. Non Vasc. 9: 314. 1972, nom. illeg; Massularia Schljak. - Nov. Syst. Plant. Non Vasc. 22: 232. 1985, nom. illeg., non (K. Schum.) Hoyle in Burtt Davy et Hoyle, Check-Lists For. Trees and Schubs Brit. Emp., No.3, Draft Descr. Check-List Gold Coast: 110. 1937.

Type species: Lophozia cornuta (Steph.) Hatt.

As a consequence the names of all species of this genus should be changed as follows:

S. cornuta (Steph.) Konst., comb. nov. Schistochila cornuta Steph., Spec. Hep. 4: 84. 1909.

S. capitata (Hook.) Konst., comb. nov. Jungermannia capitata Hook., Brit. Jungerm.: tab. 80. 1816.

S. laxa (Lindb.) Konst., comb. nov. - Jungermannia laxa Lindb., Acta Soc. Sci. Fenn. 10: 529. 1875.

S. grandiretis (Lindb.) Konst., comb. nov.Jungermannia grandiretis Lindb. in Kaal., Nyt. Mag. Naturvid. 33: 322. 1893.

S. nakanishii (Inoue) Konst., comb. nov. Lophozia nakanishii Inoue, Bull. Natl. Sci. Mus. (Tokyo) 9: 37. 1966.

S. incisa (Schrad.) Konst., comb. nov. Jungernannia incisa Schrad., Syst. Samml. Krypt. Gew. 2: 5. 1796.

S. opacifolia (Meyl.) Konst., comb. nov. Lophozia opacifolia Culm ex Meyl., Hep. Suisse: 174. 1924.

S. hyperarctica (Schust.) Konst., comb. nov. - Lophozia hyperarctica Schust., Canad. J. Bot. 39: 967. 1961.

S. elegans (Schust.) Konst., comb. nov. Lophozia excisa (Dicks.) Dum. var. elegans Schust., Hep. Anthoc. North Amer. 2: 522. 1969; Massula elegans (Schust.) Schljak. Pechenochnye mkhi Severa SSSR, 3: 68. 1980, nom. illeg.

S. setosa (Mitt.) Konst., comb. nov. - Jungermannia setosa Mitt. - J. Proc. Linn. Soc., Bot. 5: 92. “1861” 1860.

\section{ANNOTATED LIST OF HEPATICS RARE OR NEW TO Sayan Mountains}

In the following list taxa new for Sayan are marked by a single asterisk, and those new for South Siberia - by a double asterisk. The main collecting localities are shown on the map (Fig.1) and mentioned in the text under the same number with following detailization of each locality. Voucher specimens are deposited in the Herbarium of Krasnoyarsk State University" and in the Herbarium of Polar-Alpine Botanical Garden of Kola Science Center of Russian Academy of Sciences (KPABG).

*Aneura pinguis (L.) Dum. - ES, 8: Mezhdurechnoe Lake, timberline, brook bank, a few plants among Saccobasis polita (5.VIII.1989).

*Riccardia latifrons (Lindb.) Lindb. - WS, 2: lower course of Golaya River, in Picea obovata - Pinus sibirica forest (17.VII.1986).

Bazzania bidentula (Steph.) Steph. - WS, 2: mouth of Malaya Golaya River, ca. $1100 \mathrm{~m}$, Picea obovata - Pinus sibirica forest, on decaying wood (26.VII.1986). The distribution of this species was discussed by Vana \& Soldan (1985) who cited the ES as the western and northern limit of this species. The locality in WS extends further its western limit.

*Calypogeia suecica ( $\mathrm{H}$. Arnell et J. Perss.) K. Muell. - ES, 7: dark coniferous forest, on logs, associated with Crossocalyx hellerianus, Cephalozia connivens, Scapania apiculata, Ptilidium pulcherrimum (13.VII.1989). There are many gemmiparous shoots as well as some plants with marsupium without any trace of anteridium in specimens. Plants pellucid to pale yellowish and pale brownish, small, about $1 \mathrm{~mm}$ wide and $4-7 \mathrm{~mm}$ long, middle leaf cells averaging 25-27 (30) $\mu \mathrm{m}$. The locality in Sayan is the second in Siberia. The first and easternmost Asiatic locality of this "by no means a rarity of mountains in central and north Europe and north America" is in the surroundings of Baikal Lake (Vana \& Soldan, 1985).

"Iwatsukia jishibae (Steph.) Kitag. - WS, 2: AlaJan River, on decaying wood, associated with Anastrophyllum michauxii and Lepidozia reptans (27.VII.1987). Many plants with perianths, male plants and a few sporophytes are presented in the specimen. Plants have numerous flagellae, relatively remote leaves, characteristic shape of leaves and female bracts, pellucid cells with walls markedly thick, and with many distinct "Tangl's canals". However, our plants differ from previous descriptions of the species in larger underleaves which are often deeply bilobed with each lobe up to 10 cells in length and 12 cells in width (cf. Schuster, 1968). Androecia on short, ventral-intercalary branches and intercalary on leading axis, spicate, of $3(4)$ pairs of closely imbricate bracts larger than leaves in size (300-420 x 350$490 \mu \mathrm{m}$ ), bracts bilobed like leaves, but usually with a discrete antical third lobe or tooth, 1-androus (Fig.2). Anteridial body subglobular, stalk 2-seriate. Capsule oblong-ovoid (most of capsules were open), 


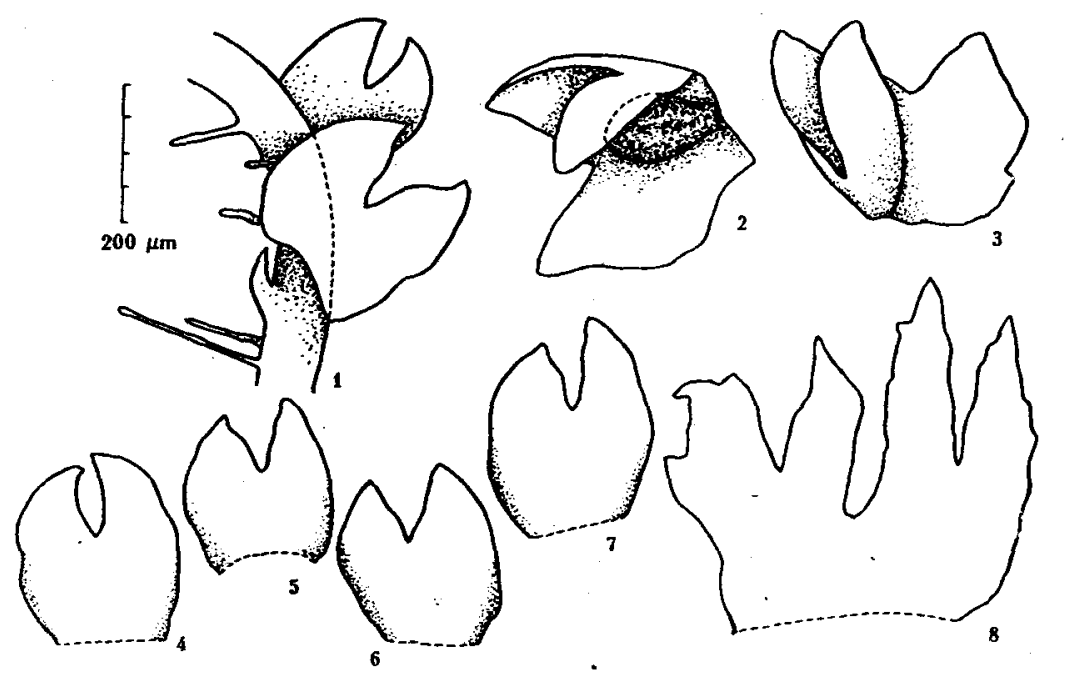

Fig. 2. Iwatsukia jishibae (Steph.) Kitag.1- Part of sterile shoot; 2,3- Male bracts; 4-7 Leaves; 8 - Female bract 4-valved to base, valves 2-stratose. Elaters 2-spiral, 6-7 $\mu \mathrm{m}$ in diam.; spores small $(8-11 \mu \mathrm{m})$, 1-celled, finely verruculose. This very rare species was previously known only from Japan, Himalaya, Costa Rica, Mauritius, Reunion and Seychelles, and Papua New Guinea (Vana \& Piippo, 1989), but recently J. Vana has found it in Altai Mts. (Konstantinova \& al., 1992). Our locality is the second in Russia.

*Pleurocladula albescens (Hook.) Grolle - WS, 5: Upper Malyi On River, rock-field, on brook hank, dominated in mats (5.VII.1968, L.B.).

${ }^{* *}$ Cephalozia connivens (Dicks.) Lindb. - ES, 7 : dark coniferous forest, on $\log$, associated with Crossocalix hellerianus, Calypogeia suecica, Scapania apiculata, Ptilidium pulcherrimum (13.VII.1989).

* Cephaloziella arctogena (Schust.) Konst., comb. nov. (Cephaloziella nubella var. arctogena Schust., in Schuster \& Damsholt, Meddel. om Gronland 199(1): 314, 1974) - WS, 2: Upper Bolshaya Ura River, alt. $1100 \mathrm{~m}$, in Larix + Betula shrubby and herbaceous forest, among Dicranum fragilifolium Lindb., Crossogyna autumnalis. In the specimen studied were many paroicous and some heteroicous plants, as well as some plants with mature sporophytes. Paroicous inflorescence, small cells (at lobe bases mostly 9-11 $\mu \mathrm{m}$ ), spores of 7-9 $\mu \mathrm{m}$, distinct underleaves and red or brown secondary pigmentation place our specimen in C. arctogena. But the cells of perianth mouth are a little longer than those described previously; averaging 9-11 x 34-43 (49) $\mu \mathrm{m}$ (Fig.3), not 7-8 x 25-38 (40) $\mu \mathrm{m}$ (Schuster, 1980, 1988; Damsholt and Long, 1983).

In the size of perianth mouth cells (as well as in paroicous inflorescence) the plants from Sayan approach to "very poorly understood" $C$. stellulifera (Schuster, 1980). They differ however from the latter in much smaller cells, presence of secondary pigmentation, and non-squarrose bract lobes. Furthermore, the cells of perianth mouth of studied plants are thin-walled and not free at their apices. This is not characteristic for $C$. stellulffera. $C$. arctogena was considered previously as an arctic subspecies of $C$. rubella (Schuster, 1980; Potemkin, 1993). The finding in Sayans changes completely distributional pattern of this taxa and provides an additional argument to distinguish it as a separate species.

**C. divaricata $(\mathrm{Sm}$.) Schiffn. var. divaricata ES, 8: Wala Range, Pinus sibirica forest, in ground vegetation, some plants among Orthocaulis kunzeanus (7.VIII.1989). Earlier from Sayans var. scabra (M.A. Howe) S. Arnell was known only (Vana \& Soldan, 1985).

C. divaricata var. scabra (M. A. Howe) S. Arnell - ES, 1: mouth of Indei Stream, Mana River Valley, on cliffs, mixed with Radula complanata (26.VI.1984). Second record in ES.

**C. subdentata Warnst. - WS, 2: Khemchikskij Range, northern slope, right bank of Aldy-Uzyk River, near trail, ca. $1590 \mathrm{~m}$., among Dicranum elongatum (1.VII.1983, A.S.).

*Orthocaulis floerkei (F. Web. et Mohr) Buch in ground vegetation of forests, open woodlands, alpine meadows, sometimes on humus among rocks on rock-fields. Common both in WS and ES.

*Barbilophozia hatcheri (Evans) Loeske - not rare in the ground vegetation of forest, in high mountains, on rock outcrops, among rocks on rock-field, etc. Both in WS and ES.

${ }^{* *}$ Leiocolea gillmanii (Aust.) Evans - WS, 3: Olenya Rechka, ca. $1400 \mathrm{~m}$, on rocks in river bed, not submerged (18.VI.1968, L.B.); EŚ, 8: Kryzhina Range, alpine meadow, on boulders, associated with Leiocolea heterocolpos, Scistochilopsis incisa, Blepharostoma trichophyllum (6.VIII.1989), and in high mountains in cliff crevices, associated with Scapania cuspiduligera, Blepharostoma trichophyllum, Preissia quadrata (6.VIII.1989); Wala Range, brook bank, associated with Scapania cuspiduligera, Blepharostoma 


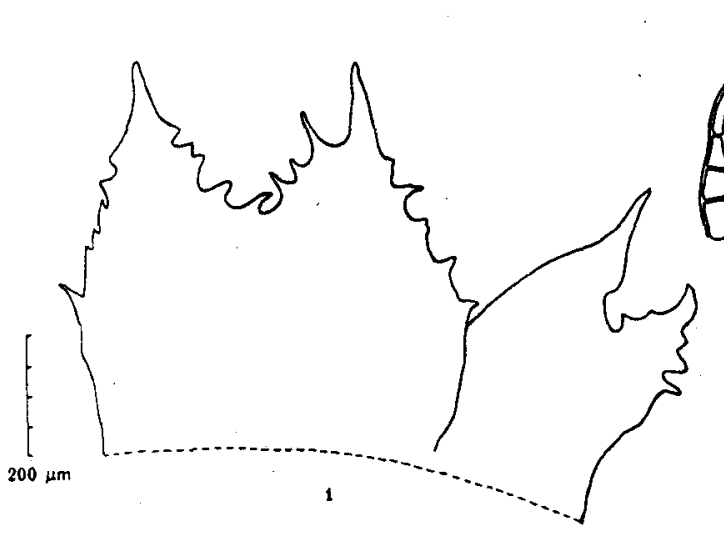

trychophyllum, Pellia neesiana (10.VIII.1991).

**L. bantriensis (Hook.) Joerg. - ES, 8: Kryzhina Range, high mountains, in crevices, associated with Preissia quadrata, Scapania cuspiduligera, Jungermannia pumila, Blepharostoma trichophyllum (6.VIII.1991).

**L. alpestris (F.Web.) Isov. - ES, 1: near Inzhul Cordon, spruce forest with Pinus sibirica, on humus and rock (20.VI.1986).

**Schistochilopsis grandiretis (Lindb.) Konst. ES, 8: Kryzhina Range, Upper Prokhodnaya River, on rocks at stream bank, associated with Schistochilopsis opacifolia, Leiocolea heterocolpos, Tritomaria scitula, Solenostoma confertissimum, Lophozia major, Blepharostoma trichophyllum, Marchantia alpestris (2.VIII.1991).

** S. opacifolia (Culm.) Konst. - ES, 8: Kryzhina Range, high mountains, on rocks, associated with Gymnomitrion concinnatum, Lophozia sudetica, Marsupella boeckii (6.VIII.1989) and Upper Prokhodnaya River, on rocks at stream bank, mixed with Blepharostoma trichophyllum, Leiocolea heterocolpos, Tritomaria scitula, Solenostoma sphaerocarpum, Lophozia major (2.VIII.1989).

**Lophozia major (C. Jens.) Schljak. - WS, 5: Upper Malyi On River, mountain tundra, on brook bank, associated with Solenostoma confertissimum, Orthocaulis quadrilobus, Cephalozia pleniceps, Blepharostoma trichophyllum, Lophozia confertifolia, Scapania cf. irrigua (4.VII.1968, L.B.); ES, 8: Kryzhina Range, Upper Prokhodnaya River, on deposit substrate on rocks at stream bank, associated with Tritomaria scitula, Schistochilopsis grandiretis, Leiocolea heterocolpos, Solenostoma confertissimum, Blepharostoma trichophyllum, Marchantia alpestris (2.VIII.1991); on rocks at stream bank, associated with Blepharostoma trichophyllum, Leiocole a heterocolpos, Tritomaria scitula, Schistochilopsis opacifolia, Solenostoma sphaerocarpum, Scapania sp. (2.VIII.1989); 9: Upper Tissa River, on brook bank, some stems among Scapania subalpina, Tritomaria quinquedentata, Blepharostoma trichophyllum, Leiocolea heterocolpos (14.VIII.1990).

*L. sudetica (Nees ex Hueb.) Grolle - WS, 2:

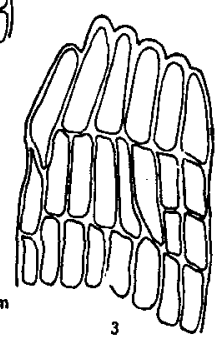

Fig. 3. Cephaloziella arctogena (Schust.) Konst. - 1- Female bract and bracteole; 2-Underleaf; 3- Sector of perianth mouth

Upper Malaya Ura River, ca. $1750 \mathrm{~m}$, at lake shore, with Gymnocolea inflata, Nardia geoscyphus (26.VII.1987); ES, 9: Upper Tissa River, high mountains, on rock-field, in depressions (10.VIII.1990).

**Gymnocolea inflata (Huds.) Dum. - WS, 2: Upper Malaya Ura River, ca.1750 m, at lake shore, in pure patches or associated with Lophozia sudetica, Nardia geoscyphus (26.VII.1987).

**Tritomaria scitula (Tayl.) Joerg. - ES, 8: Upper Prochodnaya River, on rocks, on stream bank, on deposit substrate, associated with Schistochilopsis grandiretis, Leiocolea heterocolpos, Solenostoma confertissimum, Lophozia major, Blepharostoma trichophyllum, Marchantia alpestris (2.VIII.1991); Wala Range, on brook bank, mixed with Blepharostoma trichophyllum, Leiocolea heterocolpos (7.VIII.1989).

Anastrophyllum michauxii (F. Web.) Buch - on decaying wood in dark coniferous forests, often with perianths, sometimes with sporophytes. Evidently not rare both in WS $(1,5)$ and ES (8).

* Saccobasis poilita (Nees) Buch - ES, 8: Mezhdurechnoe Lake, timberline, on brook bank, female plants in pure tuft, plants with antheridia - mixed with mosses and Aneura pinguis (5.VIII.1989).

**Nardia geoscyphus (De Not.) Lindb. - WS, 2: Upper Malaya Ura River, ca. $1750 \mathrm{~m}$, at lake shore, associated with Lophozia sudetica, Gymnocolea inflata (26.VII.1987); ES, 8: Kryzhina Range, high mountains, on cliff, associated with Cephalozia pleniceps, Tritomaria quinquedentata, Blepharostoma trichophyllum, Leiocolea heterocolpos (6.VIII.1989).

**Jungermannia pumila With. - ES, 8: Kryzhina Range, high mountains, in crevices, associated with Preissia quadrata, Scapania cuspiduligera, Leiocolea bantriensis, Blepharostoma trichophyllum (6.VIII.1991), and on cliff, associated with Blepharostoma trichophyllum, Solenostoma confertissimum (6.VIII.1989).

**Solenostoma confertissimum (Nees) Schljak. - WS, 5: Upper Malyi On River, on brook bank, associated with Lophozia major, Orthocaulis quadrilobus, Cephalozia pleniceps, Blepharostoma trichophyllum var. brevirete, Lophozia confertifolia, 


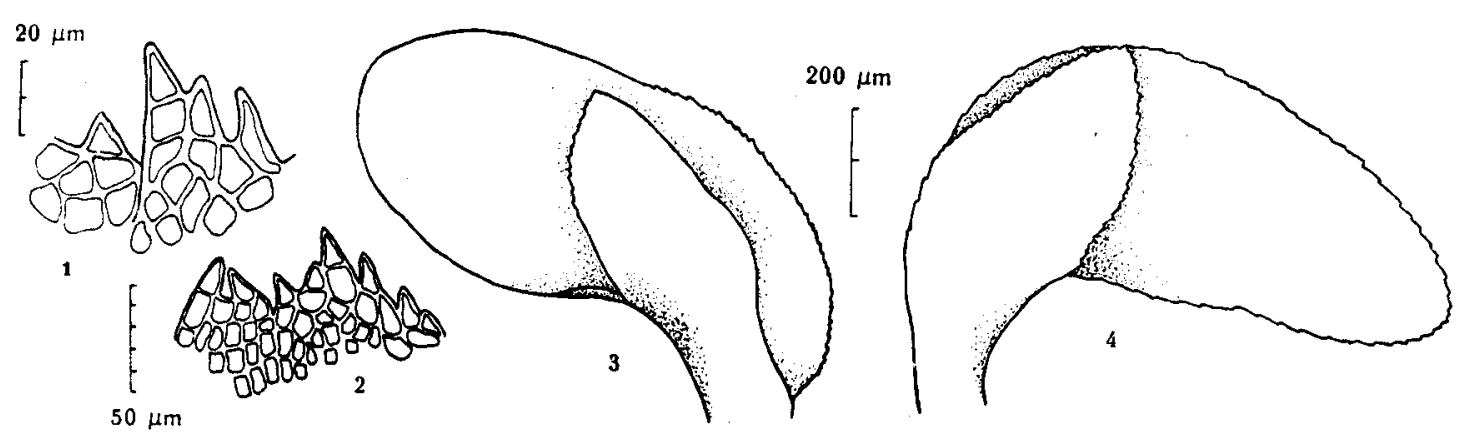

Fig. 4. Diplophyllum obtusatum Schust. 1-2 - Sectors of perianth mouth; 3-4 Leaves.

Scapania cf. imigua (4.VII.1968, L.B.); 3: near Olenya Rechka, ca. $1400 \mathrm{~m}$, on rocks in stream, some stems among Plectocolea obovata, Leiocolea gillmanii (18.VI.1968, L.B.); ES, 8: Upper Prokhodnaya River, on stream bank, on deposit substrate, on rocks, among Schistochilopsis opacifolia, S. grandiretis, Leiocolea gilImanii, Tritomaria scitula, Lophozia major, Blepharostoma trichophyllum, Marchantia alpestris (2.VIII.1991).

**S. sphaerocarpum (Hook.) Steph. var. nana (Nees) Schust. - ES, 9: Upper Tissa River, high mountains, on stream bank, associated with Scapania obcordata and Anthelia juratzkana (8.VIII.1990); 8: Upper Prokhodnaya River, on stream bank, on rocks, associated with Blepharostoma trichophyllum, Leiocolea heterocolpos, Tritomaria scitula, Schistochilopsis opacifolia, Lophozia major, Scapania sp. (2.VIII.1989). Status of this taxon is problematic (cf. Schuster, 1988; Koponen et al., 1977; Potemkin, 1993) but we believe that it will be better to distinguish it. Sayanan plants differ from typical $S$. sphaerocarpum in smaller size of shoots (to $10 \mathrm{~mm}$ long $\mathrm{x} 0.6 \mathrm{~mm}$ wide), leaves (ca. 550-600 x 400-450 $\mu \mathrm{m}$ ) and cells (marginal ca. 18-20 $\mu \mathrm{m}$ and median ca. 20-23 $\mu \mathrm{m}$ ) as well as more broad leaves (width:length ratio $1.1-1.3$ !). They differ from $S$. confertissimum in not fasciculate rhizoides, arising from stem only, and the absence of any trace of vinaceous pigmentation.

Plectocolea obovata (Nees) Lindb. - WS, 3: near Olenya Rechka, ca. 1400 , on rocks in stream, associated with Scapania subalpina, Leiocolea gillmanii, Solenostoma confertissimum, (18.VI.1968, L.B.); ES, 3: near Olenya Rechka, Oiskoe Lake, submerged (31.VII.1966). Previously this species was known from the mountain Altaen in WS only (Kaalas, 1918).

Gymnomitrion concinnatum (Lightf.) Corda on rock outcrops, evidently not rare in upper belts of both ES and WS. Previously was reported from ES only (Vana, 1988).

**Marsupella sphacelata (Gierske ex Lindenb.) Dum. - WS, 3: Olenya Rechka, ca. $1400 \mathrm{~m}$, on rocks in brook, submerged, associated with Scapania undulata (20.VI.1968, L.B.).

${ }^{* *}$ M. boeckii (Aust.) Lindb. ex Kaal. - ES, 8:
Kryzhina Range, high mountains, on rock outcrops, associated with Gymnomitrion concinnatum, Lophozia sudetica, Schistochilopsis opacifolia (6.VIII.1989).

Macrodiplophyllum microdontum (Mitt.) $\mathrm{H}$. Perss. - WS, 2: Upper Golaya River, high mountains, rock-field, in depressions, pure mats (29. VII.1986). Previously it was recorded for ES (Vana \& Soldan, 1985). Our locality is the westernmost.

**Diplophyllum obtusatum (Schust.) Schust. ES, 9: upper part of Tissa River basin, light Larix forest, on boulder, on edge of mat of Scapania scandica, Tritomaria quinquedentata, Sphenolobus minutus (3.VIII.1990). First locality in Eurasia. This taxon has been described by Schuster (1974) from Minnesota, and occurred just in few localities in North America. In Sayan only some stems of this species were collected, but they were distinctly autoicous with antheridia disposed on branches with small leaves beneath perianth. This species can be distinguished from closely allied $D$. obtusifolium as follows:

- Autoicous, with numerous subfloral, often male innovations; antheridia disposed on abbreviated (shorter than adjacent leaves of the main shoots) branches with small reduced bracts, perianth bordered by 1-2-celled teeth with apical cell usually elongated but its length:width ratio do not exceed 1:2 and more often is 1:1.5 (in plants from Sayan the more elongated apical cells are 9-12 x 17-22 $\mu \mathrm{m}$ ), cells of teeth up to $18-20 \mu \mathrm{m}$ wide (in Sayan plants about 14-15 $\mu \mathrm{m}$ ); gemmae usually present (in Sayan specimens gemmae not found may be because of very sparse material with perianth and male innovations on each stem, cf. Schuster, 1974: 219, footnote); dorsal lobe with subacute or weakly apiculate apex (Fig. 4), cells coarsely papillose ................. D. obtusatum

- Paroicous, male bracts large, situated below perianth near apex of leading stems; subfloral innovations only exceptionally developed; perianth mouth with some or many teeth formed of 2-3 elongated cells, the wide-length ratio of apical cells often more than 1:2 and can exceed 1:3 (4); gemmae usually absent; dorsal lobe broadly rounded at the apex, cells usually more or less fainly papillose ..... D. obtusifolium 
*D. obtusifolium (Hook.) Dum. - WS, 2: Lower Golaya River, on rock outcrops in shade, several stems among Sphenolobus minutus (17.VII.1986).

*Scapania apiculata Spruce - ES, 7: dark coniferous forest, on log, associated with Crossocalix hellerianus, Cephalozia connivens, Calypogeia suecica, Ptilidium pulcherrimum (13.VII.1989). The second locality in Asia, the first one is in surroundings of Baikal Lake (Vana, 1988). Some plants with anteridia; the only one shoot with very small $(9-11 \mu \mathrm{m})$ onecelled red gemmae was found in our collections. Leaf cells with characteristic very coarse bulding trigones.

*S. crassiretis Bryhn - WS, 2: Malaya Golaya River mouth, ca. $1100 \mathrm{~m}$, at river bank, on rocks, associated with $S$. rufidula and Tritomaria exsecta (26.VII.1990); Lower Golaya River, on cliff, associated with Sphenolobus minutus and Diplophyllum obtusifolium (17.VII.1986); ES, 9: Upper Tissa River, high mountains, rock-field, on rocks covered with humus, associated with $S$. spitsbergensis, Tritomaria quinquedentata (10.VIII.1990).

S. cuspiduligera (Nees) K. Muell. - ES, 8 : Kryzhina Range, high mountains, in cliff crevices, mixed with Blepharostoma trichophyllum, Leiocolea gillmanii, Preissia quadrata (6.VIII.1989); WS, 5: Bolshoi On River, ca. $1050 \mathrm{~m}$, on rocks at river bank (14.VII.1968, L.B.). Previously was recorded from ES (Vana, 1988).

**S. gymnostomophila Kaal. - ES, 1: Mana River, near Cordon Berdy, dark coniferous forest, on rocks, several shoots scattered among Amphidium lapponicum (4.VIII.1985).

** S. kaurinii Ryan - ES, 9: Upper Tissa River, high mountains, rock-field, on rocks covered with humus, associated with $S$. spitsbergensis and Tetralophozia setiformis (10.VIII.90). The record of this rather rare and poorly known taxon in Sayan is of great interest. According Schuster (1974), many records of $S$. kaurinii from America are doubtful. In our specimens some clearly paroicous plants were found. They are characterized also by lobulate-ciliate perianth mouth, typical "kaurinii" shape of leaves, small trigones of cells, mostly two-celled, greenish mixed with purple gemmae averaging 17-20 × 20-29 $\mu \mathrm{m}$.

**S. obcordata (Berggr.) S. Arnell - ES, 9: Upper Tissa River, high mountains, on stream bank, associated with Solenostoma sphaerocarpum var. nana and Anthelia juratzkana (8.VIII.1990).

**S. paludicola Loeske et K. Muell. - WS, 4: Upper Karasu River, ca. $1850 \mathrm{~m}$, swampy meadow, near pool (6.VII.1968, L.B.).

*S. rufidula Warnst. - WS, 2: Malaya Golaya River mouth, ca.1100 m, on rocks at stream bank, associated with Scapania crassiretis (26.VII.1986); Lower Malaya Golaya River, on deposit substrate on rocks at river bank (17.VII.1986); 3: Olenya Rechka, rock-field; on rocks covered with humus, mixed with Tritomaria quinquedentata (20.VI.1968, L.B.).

*S. scandica (H. Arnell et Buch) Macv. f. parvifolia (Warnst.) Schljak. - ES, 9: Upper Tissa River, Larix sibirica + Pinus sibirica light forest, on humus on boulder, associated with Schistochilopsis opacifolia, Blepharostoma trichophyllum, Sphenolobus minutus (14.VIII.1990); Pinus sibirica light forest, on fine soil layer on boulder, mixed with Cephalozia bicuspidata (4.VIII.1990); light Larix forest, on rocks, associated with Diplophyllum obtusatum, Tritomaria quinquedentata, Sphenolobus minutus (3.VIII.1990); ES, Saryg-Sen, ca. $750 \mathrm{~m}$, in spruce forest (Picea obovata), on decaying stump, mixed with Lophocolea heterophylla (24.VII.1968, L.B.).

*S. sphaerifera Buch et Tuomik. - WS, 2: Malaya Golaya River mouth, ca. $1100 \mathrm{~m}$, Pinus sibirica forest, on boulder, in one specimen mixed with Andreaea rupestris and Sphenolobus minutuis, in another - several stems with perianths, mixed with Andreaea rupestris, Tritomaria exectiformis, Sphenolobus saxicola (26.VII.1986).

*S. spitsbergensis (Lindb.) K.Muell. - WS, 2: Malaya Golaya River mouth, ca. $1100 \mathrm{~m}$, on rocks at river bank, associated with Tritomaria execta (26.VII.1986); 3: Olenya Rechka, ca. $1400 \mathrm{~m}$, rockfield, on rocks covered with humus, associated with Gymnomitrion concinnatum, Marsupella emarginata, Blepharostoma trichophyllum, Tritomaria quinquedentata, Barbilophozia hatcheri (20.VI.1968, L.B.); ES, 9: Upper Tissa River Basin, high mountains, rockfield, on rocks covered with humus, mixed with Cephalozia bicuspidata, Leiocolea heterocolpos or Barbilophozia hatcheri, Marsupella emarginata, Tetralophozia setiformis, Gymnomitrion concinnatum, Tritomaria quinquedentata (10.VIII.1990).

*S. subalpina (Nees ex Lindenb.) Dum. - WS, 3: Olenya Rechka, ca. $1400 \mathrm{~m}$, on rocks in river bed, plants with perianths and sporophytes, mixed with Plectocolea oboviata, Leiocolea gillmanii, Solenostoma confertissimum (18.VI.1968, L.B.); ES, 8: Wala Range, timberline, brook bank, with Marchantia alpestris (7.VIII.1990); 9: Upper Tissa River basin, Larix forest, brook bank, on fine soil layer on rocks (9.VIII.1990); Upper Tissa River, brook bank, with Tritomaria quinquedentata, Blepharostoma trichophyllum, Leiocolea heterocolpos, Lophozia major (14.VIII.1990).

*S. uliginosa (Lindenb.) Dum. - ES, 9: Upper Tissa River, stream bank in light Larix forest, with $S$. subalpina, Blepharostoma trichophyllum var. brevirete, Lophozia major, Tritomaria quinquedentata, Leiocolea heterocolpos (14.VIII.1990).

S. undulata (L.) Dum. - WS, 3: Olenya Rechka, ca. $1400 \mathrm{~m}$, on rocks in brook, submerged, mixed with Marsupella sphacelata (20.VI.1968, L.B.). Pre- 
viously was recorded for ES (Vana, 1988).

*Mannia fragrans (Balb.) Frye et Clark - ES, 1: Mana River, Khaidynka, on cliff (3.VIII.1985).

Pressia quadrata (Scop.) Nees ES, 8: Kryzhina Range, high mountains, in cliff crevices, with Scapania cuspiduligera, Blepharostoma trichophyllum, Leiocolea gillmanii (6.VIII.1989). Previously was known from WS (Vasiljev, 1992).

**Marchantia alpestris (Nees) Burgeff: ES, 8: Upper Prokhodnaya River, river bank, on deposit substrate on rocks, associated with Schistochilopsis opacifolia, S. grandiretis, Leiocolea heterocolpos, Tritomaria scitula, Solenostoma confertissimum, Lophozia major, Blepharostoma trichophyllum (2.VIII.1991), and Wala Range, timberline, brook bank, mixed with Scapania subalpina (7.VIII.1989).

\section{Discussion}

Most of the species listed above are more or less common hepatics. Many of them have hypoarctomontane distribution (Leiocolea gillmanii, $L$. bantriensis, L. alpestris, Lophozia sudetica, Tritomaria scitula, Scapania scandica, S. paludicola, S. subalpina). Boreal species are fewer (Riccardia latifrons, Cephaloziella divaricata, Gymnocolea inflata) as well as arctoalpine species (Pleurocladula albescens, Schistochilopsis opacifolia) and montane hepaticae (Jungermannia pumila). One of the new for Sayan records is believed to be a cosmopolitan species (Aneura pinguis). Predominance of hypoarcto-montane species among listed above hepatics may be explained by comparatively poorly explored upper belt of the Sayans.

However, besides these common species there were found several hepatics having sporadic distribution in the world (Schistochilopsis grandiretis, Diplophyllum obtusifolium, Scapania spitsbergensis, S. kaurinii, Lophozia major, Calypogeia suecica).

The recent discovery in Sayans of some hepatics change considerably their phytogeographical patters. So, some species (Nardia geoscyphus, Marsupella sphacelata, M. boeckii, Scapania undulata) previously were reported as oceanic species (Schljakov, 1981). Orthocaulis floerkei was known as "species with a rather disjunct, suboceanic distribution in the Northern Hemisphere: Europe, western and eastern North America and two locations in the Far East..." (Gradstein \& Vana, 1987). However it appears to be widespread in Sayan and evidently in the whole South Siberia. Saccobasis polita and Plectocolea obovata were known earlier as European-American species (Schljakov, 1980, 1981).

Of the special interest is the repeated collection of Scapania sphaerifera in the Western Sayan; earlier it was reported for Eastern Sayan (Vana \& Soldan, 1987). Collections of Macrodiplophyllum microdontum and Scapania rufidula, rather rare eastern asiatic spe- cies in Western Sayan are the most western localities for both of them.

The remarkable record is the little known species Diplophyllum obtusatum, previously known from North America only.

A number of hepatics were found to be much more widespread in Sayans than it was previously known: Lophozia longiflora, L. confertifolia, Cephalozia pleniceps, C. Iunulifolia, C. leucantha, Obtusifolium obtusum, Schistochilopsis incisa, Orthocaulis kunzeanus, Marsupella emarginata, Mylia taylorii. They were recorded from one or two localities, but in fact appears to be not rare in both Western and Eastern Sayan.

Combining all available data, the flora of Hepaticae of Sayan Mts. includes 127 species. Certainly, it is not a limit, and further investigations will reveal many rare and interesting hepatics.

\section{The List of Hepatics of Sayan Mts.}

(! - species revised by the senior author)

Anastrophyllum michauxii (F.Web.) Buch !

Aneura pinguis (L.) Dum.!

Anthelia juratzkana (Limpr.) Trev.!

Apometzgeria pubescens (Schrank) Kuwah. (Vasiljev, 1992)

Amellia fennica (Gott.) Lindb.!

Asterella saccata (Wahlenb.) Evans (Vasiljev, 1992)

Barbilophozia barbata (Schmid. ex Schreb.) Loeske!

$B$. hatcheri (Evans) Loeske!

B. lycopodioides (Wallr.) Loeske !

Bazzania bidentula (Steph.) Steph!

B. tricrenata (Wahlenb.) Lindb. (Vasiljev, 1992)

Blasia pusilla L. (Vana, 1988)

Blepharostoma trichophyllum (L.) Dum.!

var. brevirete Bryhn et Kaal.!

Calypogeia integristipula Steph.!

C. muelleriana (Schiffn.) K.Muell. (Vasiljev, 1992)

C. neesiana (C.Mass. et Carest.) K.Muell. (Vasiljev, 1992)

C. suecica (H.Arnell et J.Perss.) K.Muell. !

Cephalozia bicuspidata (L.) Dum.!

C. connivens (Dicks.) Lindb.!

C. leucantha Spruce!

C. lunulifolia (Dum.) Dum.!

C. pleniceps (Aust.) Lindb. !

Cephaloziella arctogena (Schust.) Konst. !

C. divaricata (Sm.) Schiffn.!

var. scabra (M.A.Howe) S.Arnell !

C. subdentata Warnst.!

Chiloscyphus polyanthos (L.) Corda (Vasiljev, 1992)

C. pallescens (Ehrh. ex Hoffm.) Dum. (Vasiljev, 1992)

Conocephalum conicum (L.) Und. (Savicz-Ljubitskaya,

1961; Vasiljev, 1992)

Crossocalyx hellerianus (Nees ex Lindenb.) Meyl. !

Crossogyna autumnalis (DC.) Schljak.!

Diplophyllum obtusatum (Schust.) Schust. !

D. obtusifolium (Hook.) Dum. !

D. taxifolium (Wahlenb.) Dum. !

Frullania bolanderi Aust. (Vana \& Soldan, 1985; Vasilev, 1992)

F. daourica Hampe (Vana, 1988; Vasiljev, 1992)

F. dilatata (L.) Dum. (Vana, 1988; Vasiljev, 1992)

F. koponenii Hatt. (Vana \& Soldan, 1985) 
F. cf. nisquallensis Sull. !

F. paroistipula Steph. (Vana \& Soldan, 1985)

Gymnocolea inflata (Huds.) Dum.!

Gymnomitrion concinnatum (Lightf.) Corda !

G. corallioides Nees !

Herbertus aduncus (Dicks.) S. Gray (Vana,1988; Vasiljev, 1992)

Isopaches bicrenatus (Schmid. ex Hoffm.) Buch !

Iroatsukia jushibae (Steph.) Kitag. I

Jungermannia pumila With.!

Leiocolea alpestris (F.Web.) Isov. !

L. bantriensis (Hook.) Joerg. !

L. gillmanii (Aust.) Evans. !

L. heterocolpos (Thed. ex Hartm.) Buch !

Lepidozia reptans (L.) Dum. !

Liochlaena subulata (Evans.) Schljak. (Vasiljev, 1992)

Lophocolea heterphylla (Schrad.) Dum. !

L. minor Nees!

Lophozia confertifolia Schiffn.!

L. excisa (Dicks.) Dum. !

L. longidens (Lindb.) Macoun!

L. longiflora (Nees) Schiffn. !

L. major (C.Jens.) Schljak. !

L. sudetica (Nees ex Hueb.) Grolle !

L. ventricosa (Dicks.) Dum. !

L wenzelii (Nees) Steph. (Vana, 1988; Vasiljev, 1992)

Macrodiplophyllum microdotum (Mitt.) H.Perss. !

Mannia fragrans (Balb.) Frey et Clark !

M. pilosa (Horn.) Frey et Clark (Vana, 1988)

$M$. sibirica (K. Muell) Frey et Clark (Vasiljev, 1992)

Marchantia alpestris (Nees) Burgeff !

M. polymorpha L.!

Marsupella boeckii (Aust.) Lindb. ex Kaal. I

M. emarginata (Ehrh.) Dum.!

M. reooluta (Nees) Dum. (Vana, 1988)

$M$. sphacelata (Gieseke ex Lindenb.) Dum. !

Metzgeria furcata (L.) Dum. (Vasiljev, 1992)

Mylia anomala (Hook.) S. Gray (Vasiljev, 1992)

M. tayloni (Hook.) S. Gray !

Nardia geoscyphus (De Not.) Lindb. !

Obtusifolium obtusum (Lindb.) S.Arnell !

Odontoschisma denudatum (Mart.) Dum. (Vana, 1988)

O. elongatum (Lindb.) Evans (Vasiljev, 1992, doubtful record)

Orthocaulis attenuatus (Mart.) Evans !

O. floerkei (F.Web. et Mohr) Buch !

O. kunzeanus (Hueb.) Buch!
O. quadrilobus (Lindb.) Buch !

Pellia neesiana (Gott.) Limpr. !

Plagiochila porelloides (Torrey ex Nees) Lindenb.!

Plectocolea obooata (Nees) Lindb. !

P. hyalina (Lyell) Mitt. (Krasnoborov, Vasiljev, 1986)

Pleurocladula albescens (Hook.) Grolle !

Porella gracillima Mitt. (Vana, 1988)

P. platyphylla (L.) Pfeiff.!

Preissia quadrata (Scop.) Nees!

Ptilidium ciliare (L) Hampe !

P. pulcherrimum (G.Web.) Vain. !

Radula complanata (L.) Dum.!

Reboulia hemisphaerica (L.) Raddi (Savicz-Ljubitskaya, 1961; Vasiljev, 1992)

Riccardia latifrons (Lindb.) Lindb. !

Ricciocarpos natans (L) Corda (Savicz-Ljubitskaya, 1961)

Riccia bifurca Hoffm. (Vasiljev, 1992)

Saccobasis polita (Nees) Buch!

Scapania apiculata Spruce!

$S$. crassiretis Bryhn!

S. cuspiduligera (Nees) K.Muell. !

$S$. gymnostomophila Kaal. !

S. hirosakiensis Steph. ex K.Muell. (Vana \& Soldan, 1985)

$S$. imigua (Nees) Nees!

S. kaurinii Ryan!

S. obcordata (Berggr.) S. Amell !

$S$. paludicola Loeske et K.Muell. !

S. rufidula Warnst.!

S. scandica (H.Arnell et Buch) Macv.!

S. sphaerifera Buch et Tuomik. !

S. spitsbergensis (Lindb.) K.Muell. !

S. subalpina (Nees ex Lindenb.) Dum. !

S. uliginosa (Lindenb.) Dum. !

S. undulata (L.) Dum. !

Schistochilopsis grandiretis (Lindb.) Konst. !

S. incisa (Schrad.) Konst. !

$S$. opacifolia (Meyl.) Konst. !

Solenostoma confertissimum (Nees) Schljak.!

$S$. gracillimum (Sm.) Schust. f. crenulatum (Mitt.) Schust (Krasnoborov \& Vasiljev, 1986)

S. sphaerocarpum (Hook.) Steph. !

Sphenolobus minutus (Schreb.) Berggr. !

S. saxicola (Schrad.). Steph. !

Tetralophozia setiformis (Ehrh.) Schljak. !

Tritomaria execta (Schmid. ex Schrad.) Loeske !

T. exectiformis (Breidl.) Schiffn. ex Loeske !

$T$ quinquedentata (Huds.) Dum.!

T. scitula (Tayl.) Joerg. !

Excluded taxa

\author{
Erroneous identification \\ Pellia epiphylla \\ Leiocolea badensis \\ Lophozia ascendens \\ Sphenolobus cavifolius \\ Scapania praeteroisa Meyl. \\ $S$. verrucosa Heeg \\ Marsupella brevissima
}

\section{AKNOWLEDGEMENTS}

We express our sincerest thanks to Dr. A. Potemkin for valuable comments on the manuscript
Corrected identification

Pellia neesiana

Lophocolea minor

Lophozia ventricosa

Different taxa

S. gymnostomophyla

Macrodiplophyllum microdontium

Lophosia sudetica

and to Diane $M$ Bridson for revising the English language of the first version of the manuscript. We are indebted to Dr. R. Schljakov for nomenclatural assistance and T. Belova for inking drawnings. 


\section{Literature Cited}

[ABRAMOVA, A. L. \& I. I. ABRAMOV] AEPAMOBA, А.Л., И. И. АБРАМОВ. 1966. Редкие мохообразные Сибири и Дальнего Востока. - [Rare bryophytes from Siberia and Far East]. Hовости cucm. rausu. pacm. [Novosti Sist. Nizsh. Rast. ]: 302-315

ARNELL, W. H. 1898. Musci novi.- Rev. Bryol, 35: 1-9.

BISANG, 1. 1991. Biosystematische Studien an Lophozia subgen. Schistochilopsis (Hepaticae). - Bryoph. Bibl, 43 : $108-135$.

[BROTHERUS, V. F. \& L. I. SAVICZ] БPOTEPУC, B.Ф., Л. И. САВИЧ 1932. Список мхов, собранных А. А. Еленкиным в 1902 году в Саянских горах и в Монголии. - [Bryophytes collected by A. A. Elenkin in 1902 in Sayan and Mongolia]. Изв. Бom. caдa AH CCCP [Izv. Bot. Sada Akad. Nauk SSSR] 30(1-2): 81-95.

DAMSCHOLT, K. \& D. G. LONG 1983. Notes on some Scandinavian Cephaloziella species; C. rubella (Nees) Warnst. var. arctogena Schust. new to Europe, the identity of C. norvegica Douin and typification of C. stellulifera (Spruce) Schiffn. - Lindbergia 9(1): 65-69.

[ELENKIN, А. А.] ЕЛЕНКИН, А. А. 1902. Краткий предварительный отчет о споровых, собранных в Саянских горах летом 1902 r. - [Brief report on cryptogams collected in Sayan in summer of 1902]. И3s. Сnб́ Бom. cada [lzv. St.-Petersb. Bot. Sada] 2(7): 218-220.

GRADSTEIN, S. R. \& J. VANA 1987. On the occurrence of Laurasian liverworts in the tropics. - Mem. New-York Bot. Gard. 45: 388-425.

KAALAAS, B. 1918. Einige Bryophyten aus dem suedlichsten Sibirien und dem Urjankailande. - Det. Kongel. Norske Vidensk. Selsk. Skrift. (1918)(2): 1-13.

KONSTANTINOVA, N. A., A. D. POTEMKIN \& R. N. SCHLJAKOV 1992. Check-list of the Hepaticae and Anthocerotae of the former USSR. - Arctoa 1: 87-127.

KOPONEN, T., P. ISOVIITA \& T. LAMMES 1977. The bryophytes of Finland: an annotated checklist. - Flora Fennica 6: 1-77.

[KRASNOBOROV, I. M. \& A. N. VASILJEV] KPACHOБОРОВ, И. М., А. Н. ВАСИЛЬЕВ]. 1986. К бриофлоре Восточного Саяна (Кутурчинское белогорье). - [On the bryoflora of the Eastern Sayan (Kuturchinskoe Belogorje). В кн.: Новое о флоре Сибири (ред. Л. И. Малынее), Новосибирск, Наука [In: Malyshev, L. I. (ed.) Novoye vo Flore Sibin, Novosibirsk, Naukal: 222-228.

[MARTYANOV, I. M.] MAPTЬЯНOB, Н. M. 1882 Материалы для флоры Минусинского края.- [On the bryoflora of Minusinskij Region.]. - Tp. O6-8a ecmecmeoucn при Импер. Казанском ун-me. [Trudy Obshch. Estestvoisp. Imp. Kazansk. Univ.] 11(3): 183.

POTEMKIN, A. D. 1993. The Hepaticae of the Yamal Peninsula, West Siberian Arctic. - Arctoa 2: 57-103.
[SAVICZ-LJUBITSKAYA, L. I.] САВИЧ-ЛЮБИЦКАЯ, Л. И. 1961. Материалы для бриофлоры Саян. - [On the bryoflora of Sayan.] Tp. 6om uн-ma AH CCCP [Trudy Bot. Inst. Akad. Nauk SSSRJ 5(9): 364-381.

[SCHLJAKOV, R. N.] ШЛЯКОВ, Р. H. 1972. Massula (K.Muell.) Schljak. - новый род комплекса Lophozia Dum. s.l. - [Massula - genus novum Lophozia Dum. s.l.] Hовосmu cucm. низи. pacm. [Novosti. Sist. Nizsh. Rast.] 9: 310-318.

[SCHLJAKOV, R. N.] ШЛЯКОВ, Р. Н. 1976, 1979-1982. Печеночники и антоцеротовые Севера СССР. т. 1-5. [The Hepaticae and Anthocerotae of the North of the USSR. Vols. 1-5] J., Наука [Leningrad, Nauka].

[SCHLJAKOV, R. N.] ШЛЯКОВ, Р. Н. 1985. Новые названия и новые комбинации для рода Massula Schljak. - [New names and combinations for the genus Massula Schljak.] Hoвости cucm. нuзu. pacm. [Novosti Sist. Nizsh. Rast. ] 22: 231-232.

SCHUSTER, R. M. 1968. Studies on Hepaticae XLV. On Iwatsukia Kitagawa. - Bull. Nat. Sci. Mus., V. 11(3): 309 317.

SCHUSTER, R. M. 1974. The Hepaticae and Anthocerotae of North America east of the hundredth meridian. Vol. 3. - New-York-London, Columbia Uniz. Press, 880.

SCHUSTER, R. M. 1980. The Hepaticae and Anthocerotae of North America east of the hundredth meridian. Vol. 4. - Nere-York, Columbia Univ. Press, 1334.

SCHUSTER, R. M. 1988. The Hepaticae of South Greenland. - Nova Hedwigia 92: 1-255.

VANA, J. 1988. Contribution to the knowledge of Liverworts (Hepaticae) of the Soviet Central Asia (East Sayan Mts., Baikal Lake). - Novit. Bot. Univ. Carol, Praha, 4: 1725.

VANA, J. \& Z. SOLDAN 1985. Some new and phytogeographically interesting bryophytes from Central Siberia. Abstracta Botanica 9 (Suppl. 2): 123-144

VANA, J. \& S. PIIPPO. 1989. Bryophyte flora of the Huon Peninsula, Papua New Guinea. XXXI. Cephaloziaceae subfam. Alobielloideae, Cephaloziellaceae, Antheliaceae and Lophoziaceae (Hepaticae). - Ann. Bot. Fennici 26: 263290.

[VASILJEV, А. N.] ВАСИЛЬEB, А. Н. 1989. Редкие и интересные виды во флоре печеночников заповедников “Столбы” и Саяно-Шушенского. - [Rare and interesting species in hepatic flora of Nature Reserves "Stolby" and "Sajano-Shushenskij".] Изв. Сибирск. Omə.AH CCCP, cep. бuол. [lzv. Sib. Otd. Akad. Nauk SSSR, Ser. Biol.] (1989)(2): 74-77.

[VASILJEV, А. N.] ВАСИЛЬEВ, А. Н. 1992. Конспект флоры мохообразных в заповедниках “Столбы” и СаяноШушенском. - [Bryophyte flora of Nature Reserves "Stolby" and "Sajano-Shushenskij"] Красноярск, Изд. Красноярского ун-та [Krasnoyarsk, Krasnoyarskij Univ.], 112. 